УДК 656.223.2.001.18

\title{
АВТОМАТИЗАЦІЯ ТЕХНОЛОГІЇ ОПЕРАТИВНОГО УПРАВЛІННЯ РУХОМИМ СКЛАДОМ
}

\author{
Канд. техн. наук Л.І. Рибальченко, магістр Н.М. Ковтун
}

\section{АВТОМАТИЗАЦИЯ ТЕХНОЛОГИИ ОПЕРАТИВНОГО УПРАВЛЕНИЯ ПОДВИЖНЫМ COCТАВОМ}

Канд. техн. наук Л.И. Рыбальченко, магістр Н.М. Ковтун

AUTOMATION TECHNOLOGY OPERATIONAL MANAGEMENT OF ROLLING STOCK

\author{
Cand. of techn. sciences L. Rybalchenko, master N. Kovtun
}

На даному етапі роботи залізниць продовжується тендениія зростання обсягів перевезень. У зв'язку з ичим необхідним стає вирішення питання щодо раціонального використання вагонів та локомотивів, задля підвищення потужності переробки більших обсягів перевезень наявним в експлуатаџї рухомим складом та уникнення витрат на придбання нового.

Ключові слова: автоматизачія, технологія, порожні вагони, раціональне використання, мінімізачія витрат.

На данном этапе работы железных дорог продолжается тенденция роста объемов перевозок. В связи с этим необходимым становится решение вопроса по рачиональному использованию вагонов и локомотивов, для повышения мощңности переработки больших объемов перевозок имеющимся в эксплуатации подвижным составом и избежания расходов на приобретение нового.

Ключевые слова: автоматизачия, технология, порожние вагоны, рациональное использование, минимизачия затрат.

At this stage, the railways continued the trend of traffic growth. In this regard, it becomes necessary solution to the problem of rational use of cars and locomotives, to increase the capacity of processing large volumes of traffic available to operate the rolling stock and to avoid the cost of purchasing a new one. The paper discusses the steps train dispatcher in the performance management technology cars in the area, and found that by performing this work in an expeditious manner, it is difficult to make the right decision, given the large number of factors affecting the economic viability of the routes taken by traffic volumes. To automate this process, it developed a model, which is based on determining the optimal route. To do this, take into account: the cost of fuel on the locomotive and wagon-clock watch on the move and simple payroll costs locomotive crew.

Keywords: automation technology, empty wagons, rational use, cost minimization.

Вступ. Не дивлячись на сучасний стан економіки та дефіцит фінансів, Укрзалізниця не відмовляється від планів подальшого розвитку. Такий курс актуалізований практично всіма регіональними залізницями, він спрямований на вирішення двох завдань: залучення додаткових вантажопотоків, сформованих системою міжнародного сполучення, i підвищення обсягів внутрішніх перевезень вантажів. Для реалізації вищевказаного стає необхідним підвищення рівня конкурентоспроможності залізниць, якості обслуговування 
клієнтів та розширення комплексу надання послуг.

Постановка проблеми у загальному вигляді. Згідно 3 текстом пояснювальної записки до фінансового плану залізниць України на 2015 р., текст якої оприлюднено на веб-сайті Міністерства інфраструктури України, протягом даного року була запланована тенденція зростання обсягу перевезень залізницями. Так вантажообіг імпортних залізничних перевезень в Україні в 2015 році на 2,1\% більше, ніж в 2014 році і $\epsilon$ найбільшим показником з імпорту [4].

Незважаючи на зменшення загальної потужності в 2015 році, в серпні цього року було навантажено у середньому на $10 \%$ вантажів більше, ніж у серпні 2014 р. Так, за період з 1.08 по 27.08.2015 р. середньодобове навантаження залізниць склало 845,2 тис. т (у той час як в серпні 2014 р. цей показник становив 765,8 тис. т). Навіть був поставлений рекорд: виконане навантаження на 92 тис. т перевищує торішній серпневий максимум, коли залізниці перевезли 851,7 тис. т вантажів. Навантаження на залізничному транспорті збільшилося за рахунок стратегічних вантажів, таких як вугілля, залізна руда і зерно [10].

Для забезпечення значних обсягів перевезень насамперед надважливою $\epsilon$ наявність достатньої кількості порожніх вагонів необхідного типу. У серпні робочий парк зерновозів налічував 13228 вагонів - на 559 од. більше, ніж у серпні 2014 р. Для забезпечення перевезень в умовах зростання обсягів вантажів 3 1.07.2015 р. робочий парк піввагонів у власності Укрзалізниці був збільшений на 135 од., а зерновозів - на 183 од. [10]. Але для зростаючих обсягів перевезень ця кількість замала, а подальше оновлення рухомого складу потребує значних витрат. Отже, постає завдання оптимізації використання наявного в експлуатації рухомого складу. Стає необхідним освоєння нових підходів до організації перевезень, таких як розподіл та подача порожніх вагонів під навантаження.

Аналіз останніх досліджень і публікацій. Проблемам, питанням та завданням, що стосуються оптимізації перевізного процесу, було приділено багато уваги. Ними займалися такі вчені та практики, як Акулінічев В.М., Бутько Т.В., Грунтов П.С., Гершвальд А.С., Данько М.I., Жуковицький I.В., Івницький В.А.,
Лаврухін О.В., Тулупов Л.П. та інші. Для різних випадків пропонувалися та розроблялися нові та удосконалені системи, технології за рахунок використання нових засобів, інформаційних систем, методів, розробок.

Визначення мети та завдання дослідження. Однією 3 важливих складових активної частини основних виробничих фондів залізничного транспорту є рухомий склад. Від рівня його технічної досконалості та стану, умов експлуатації, системи ремонту та обслуговування залежать результати діяльності транспорту в цілому. Аналіз вікового стану експлуатаційного парку рухомого складу вказує на його майже критичний стан. Таким чином, у найближчій перспективі одним 3 першочергових завдань залізниць $є$ оновлення рухомого складу, що може здійснюватися за рахунок як придбання нової техніки, так i модернізації існуючої. В обох випадках це вимагає значних капітальних вкладень. В умовах нестачі інвестицій раціональним вирішенням такого питання може бути удосконалення технології та раціоналізація використання рухомого складу, який $\epsilon$ y наявності на даному етапі.

Основна частина. Чітка i безперебійна робота залізничного транспорту багато в чому залежить від рівня професійної підготовки диспетчерського персоналу. Основна функція диспетчерів - прийняття керуючих рішень. До завдань диспетчера входять оцінка ситуації, вибір рішення, моделювання в пам'яті роботи станції, вузла, дільниці, полігону за обраним рішенням і прогнозування майбутньої ситуації $[3,5]$. Розподілення основних диспетчерських функцій за трудомісткістю наведено на рис. 1.

У рис. 1:

1 - запис та передача диспетчерських наказів про поїзди на роздільні пункти;

2 - введення графіка виконаного руху та додатки до нього;

3 - вибір варіантів диспетчерського регулювання;

4 - збір відомостей із роздільних пунктів, у тому числі про зайнятість колій;

5 - отримання інформації про поїзди, обмін підходами;

6 - установка маршрутів (при ДЦ);

7 - поточний облік приймання-здавання вагонів та інших показників експлуатаційної роботи. 


\section{Експлуатація залізниць}

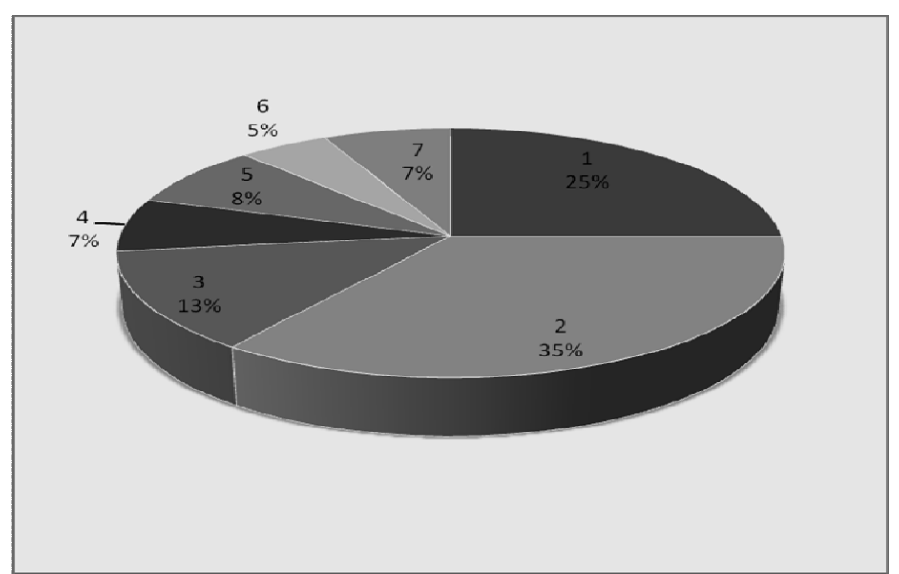

Рис. 1. Розподілення основних диспетчерських функцій за трудомісткістю

Здійснити подачу вагонів під навантаження треба точно у визначений термін, що вказаний у заявці вантажовласника. Це не легке завдання, адже на станції навантаження не завжди $є$ потрібна кількість порожніх вагонів необхідного типу, тож їх треба доставити 3 інших станцій полігону. Тип, кількість вагонів, категорію поїзда та маршрут, за яким будуть доставлені вагони під навантаження 3 інших станцій, вирішують головний вагонорозподілювач та поїзний диспетчер [6]. Крім цього, вони забезпечують утримання вагонного парку на дорогах мережі відповідно до встановлених норм, а також виконання навантаження найважливіших вантажів у розмірах, встановлених добовим планом. Для вирішення цих завдань вони постійно контролюють наявність вагонних парків на дорогах мережі i пересування регулювальних маршрутів. За допомогою одержання даних про передачу вагонів за типом рухомого складу через міждорожні стикові пункти i забезпеченості залізниць навантажувальними ресурсами головний вагонорозподілювач контролює виконання регулювальних завдань. Вплив на хід перевізного процесу на дорогах мережі він здійснює за допомогою реалізації таких оперативних заходів: вказівок щодо обстановки, переміщення та вилучення вагонів 3 резерву; збільшення або обмеження норм навантаження за окремими призначеннями; зміни схем пропуску порожніх складів та окремих груп вагонів; підготовки та видачі завдань по здачі з-під вивантаження вагонів за типом рухомого складу $[7,8,9]$.

Диспетчер для успішного виконання всіх покладених на нього функцій повинен володіти навичками швидкого прийняття рішень. Як би добре він не знав технологію роботи, такі навички можна отримати тільки на практиці. 3 накопиченням досвіду роботи в пам'яті диспетчера формується певний набір різних ситуацій і ряд їх раціональних рішень. Та виконуючи цю роботу в оперативному порядку, важко прийняти правильне рішення 3 урахуванням великої кількості різних факторів, які впливають на економічну доцільність маршрутів прямування вагонопотоків та раціональне використання вагонного парку $[1,3]$. Багаторазово прискорити і полегшити цей процес можна за допомогою його автоматизації.

Для автоматизації вищевказаного процесу прийняття рішень та мінімізації витрат на доставку вагонів необхідно розробити модель, в основі якої буде лежати визначення раціонального маршруту. Для цього необхідно врахувати всі витрати та умови здійснення подачі вагонів. До них можна віднести витрати на паливо, локомотиво-години у русі та простої, вагоно-години у русі та простої, заробітну плату локомотивної бригади. Отже, цільова функція в неявному вигляді буде такою:

$$
f(c)=c_{1}^{n}+c_{2}^{\pi p}+c_{3}^{\pi n}+c_{4}^{8 p}+c_{5}^{8 n}+c_{6}^{3 n} \rightarrow \min ,
$$


де $c_{1}^{n}$ - витрати на паливо, грн;

$c_{2}^{\pi p}$ - витрати на локомотиво-години у русі, грн;

$c_{3}^{\text {sn }}$ - витрати на локомотиво-години у простої, грн;

$c_{4}^{6 p}$ - витрати на вагоно-години у русі, грн;

$c_{5}^{6 n}$ - витрати на вагоно-години у простої, грн;

$c_{6}^{3 n}$ - витрати на заробітну плату локомотивної бригади.

Далі необхідно врахувати обмеження та привести цільову функцію у явний вигляд. До обмежень відносяться: кількість вагонів у складі поїзда 3 урахування допустимої маси та довжини на дільниці або перегоні; час руху між станціями, що не повинен перевищувати термін подачі під навантаження, вказаний у заявці; час зміни локомотивної бригади. Після приведення функції у явний вигляд необхідно визначитися зі способом іiі вирішення. Диспетчеру важко виконувати такі достатньо складні та займаючі немало часу розрахунки в оперативному режимі багато разів на зміну, тому потрібно автоматизувати цей процес. Для цього необхідно визначитися 3 методом. Одним із багатьох є метод перебору варіантів, та його значний недолік - тривалий пошук рішення. Отже, маємо знайти якийсь аналог. Таким методом $є$ генетичні алгоритми [2]. Його використання забезпечить більшу швидкість отримання результату, а його спроможність до адаптування $\epsilon$ дуже важливою для поставленого завдання, адже вона стосується оперативного планування, яке здійснюється в постійно мінливих умовах.

Таким чином, виявлено необхідність подальшої роботи щодо розробки автоматизації технології розподілу та доставки вагонів.

Висновки. На основі статистичних даних виявлено зростання обсягів навантажень, що викликає необхідність реагування залізниць швидкою подачею порожніх вагонів "точно в строк”. Та виконання цієї умови ускладняється нестачею рухомого складу. В роботі запропоновано раціональне використання наявних вагонів 3 оптимізацією витрат на доставку на основі автоматизації технології їх подачі.

\section{Список використаних джерел}

1. Гершвальд, А.С. Оптимизация оперативного управления процессами грузовых перевозок на железнодорожном транспорте [Текст] / А.С. Гершвальд. - М.: Интертекст, 2001. - 240 с.

2. Гладков, Л.А. Генетические алгоритмы [Текст] / Л.А. Гладков, В.В. Курейчик, В.М. Курейчик. - М.: Физматлит, 2006. - 320 с.

3. Грошев, Г.М. Пособие поездному диспетчеру и дежурному по отделению [Текст] / Г.М. Грошев, В.А. Кудрявцев, Г.А. Платонов, А.Д. Чернюгов. - М.: Транспорт, 1992. - 368 с.

4. Грузооборот импортных железнодорожных перевозок в Украину в 2015 году будет максимальным почти за 20 лет [Электронный ресурс]. - Режим доступа: http://www.ukrrudprom. com/news/Gruzooborot_importnih_gd_perevozok_v_Ukrainu_v_2015_godu_budet_m.html.

5. Единый диспетчерский центр [Электронный ресурс]. - Режим доступа: http: // www.uzrailway.uz/rus_p_8_p_3.html.

6. Заглядимов, Д.П. Организация движения на железнодорожном транспорте [Текст] / Д.П. Заглядимов. - М.: Транспорт, 1985. - 356 с.

7. Інструктивні вказівки з організації вагонопотоків на залізницях України [Текст]: офіц. текст. - К.: Мін-во транспорту та зв'язку України, Державна адміністрація залізничного транспорту України, головне управління перевезень, 2005. - 99 с.

8. Інструкція з оперативного планування поїзної і вантажної роботи на залізницях України: [Текст]: офіц. текст № 969-ЦЗ [прийнято та надано чинності наказом Укрзалізниці від 15 грудня 2004 p.]. - К.: Мін-во транспорту та зв'язку України, Державна адміністрація залізничного транспорту України, головне управління перевезень, 2004. - 48 с.

9. Інструкція з руху поїздів і маневрової роботи на залізницях України [Текст]: офіц. текст. К.: Мін-во транспорту та зв'язку України, Державна адміністрація залізничного транспорту України, головне управління перевезень, 2005. - 458 с. 


\section{Експлуатація залізниць}

10.Укрзализныця поставила очередной рекорд [Электронный ресурс]. - Режим доступа: http://transport-journal.com/news/ukrzalyznyitsya-postavyla-ocherednoj-rekord-pohruzky/.

Рецензент д-р техн. наук, професор О.М. Огар

Рибальченко Лілія Ігорівна, кандидат технічних наук, старший викладач кафедри управління експлуатаційною роботою Українського державного університету залізничного транспорту. Тел.: (057) 730-10-88.

E-mail: rubalchenko_liliya@mail.ru.

Ковтун Наталія Михайлівна, студентка факультету управління процесами перевезень Українського державного університету залізничного транспорту, спеціальність “Організація перевезень та управління на транспорті (залізничний транспорт)”. E-mail: kovtun.n1993@gmail.com.

Rybalchenko Liliya Igorivna, c-t science, Lecturer department of management of operational work Ukrainian State University of Railway Transport. Tel.: (057) 730-10-88. E-mail: rubalchenko_liliya@mail.ru.

Natalia Kovtun, student of management processes of transport Ukrainian State University of Railway Transport, specialty "Organization of transport and management of transport (rail)." E-mail: kovtun.n1993@gmail.com.

Стаття прийнята 07.09.2015 p. 